Bangladesh J. Bot. 40(2): 113-120, 2011 (December)

\title{
TAXONOMIC REVISION OF THE GENUS MORINDA L. (RUBIACEAE) IN BANGLADESH
}

\author{
Sujit C Das and M Atiqur Rahman \\ Department of Botany, University of Chittagong, Chittagong-4331, Bangladesh
}

Key words: Taxonomy, Morinda, Rubiaceae, Bangladesh

\begin{abstract}
The genus Morinda L. (Rubiaceae) has been revised for its species diversity in the flora of Bangladesh. The genus is represented by five species, viz., M. angustifolia Roxb., M. citrifolia L., M. persicaefolia Ham., M. pubescens Smith and M. umbellata L. Of these, M. pubescens Smith is a new record for Bangladesh. A key to the species with vernacular names, descriptions, illustrations, photographs, ecology, uses, geographical distribution and status of occurrence in the flora is provided.
\end{abstract}

\section{Introduction}

The genus Morinda L. (Rubiaceae) is represented by 80 species in the tropical regions of the world (Mabberley 1997). Most of the species of the genus originated in the regions of Borneo, New Guinea, Northern Australia and New Caledonia. Survey of relevant floristic literature, such as, Wallich (1828-1849), Roxburgh (1814, 1832), Voigt (1845), Kurz (1877), Hook. (1880), Heinig (1925), Raizada (1941), Sinclair (1956), Prain (1903), Dey et al. (1998), Rashid et al. (1999) and Rahman and Das (2009) revealed four species, such as, M. angustifolia, M. citrifolia, M. persicaefolia and M. umbellata recorded from Bangladesh. Extensive field survey throughout Bangladesh and examination of a large number of collected herbarium specimens of the Rubiaceae available at ABD, CAL, E, K, DACB, Salar Khan Herbarium at Dhaka University (SKHDU), the Herbaria of Chittagong University (HCU), Bangladesh Forest Research Institute (BFRIH) and Bangladesh Council of Scientific and Industrial Research (BCSRIH) resulted in one more species which is Morinda pubescens Smith. It was previously known to occur in Sri Lanka, India and Malayan Archipelago.

\section{Materials and Methods}

Plants of the family Rubiaceae were collected from eastern part of Bangladesh, especially from the forests of Chittagong, Chittagong Hill Tracts and greater Sylhet district through extensive field surveys under Aberdeen University-Chittagong University Biodiversity Link Project. Moreover, specimens preserved at DACB, SKHDU, BFRIH and BCSIRH were borrowed at the Herbarium of Chittagong University (HCU). The identifications were confirmed by matching with the identified specimens available at ABD, BM, CAL, E and K. Nomenclature was updated following ICBN's rules, and by consulting recently published literature on the Rubiaceae and by searching internet.

A key to the species of the genus Morinda L. is prepared with the easily observable field characters, and taxonomic enumeration of all the five species are presented with updated nomenclature, commonly known synonyms, vernacular names, descriptions, illustrations, ecology, uses, geographical distribution and status of occurrence. A list of examined specimens of each species is also provided. 


\section{Results and Discussion}

A total of five species of Morinda (Rubiaceae), such as M. angustifolia Roxb., M. citrifolia L., M. persicaefolia Ham., M. pubescens Smith and M. umbellata L.

Morinda L., Sp. Pl.: 176 (1753); Hook.f., Fl. Brit. Ind. 3:157 (1880-1881). Syn: Belicia Lundell, Bellynkxia Mull. Arg.; Guttenbergia Zoll. et Moritzi; Imantina Hook. f.; Pogonanthus Montr.; Rojoc Adans.; Sphaerophora Bl., Stigmanthus Lour.; Stigmatanthus Roem. et Schult.

Type: M. royoc L. (vide Hitchcock, Prop. Brit. Bot. 132. Aug. 1929) [Lectotype].

\section{Key to the species}

1. Trees or large shrubs; flowers in simple or panicled peduncled head, corolla tube elongate

- Climbing shrubs; flowers in umbellate peduncled head, corolla tube short

2. Leaves pubescent or tomentose, stipules usually bifid or very large, linear, seeds not winged

M. pubescens

- Leaves glabrous, stipules not bifid, seeds winged below

3. Leaves lanceolate to elliptically lanceolate, acuminate at both ends, long petioled, quite glabrous or minutely scabrous; low shrub

M. persicaefolia

- Leaves obovate to elliptic; shrub or small tree

4. Leaves obovate-lanceolate, stipules acute

M. angustifolia

Leaves broad, elliptic, stipules obtuse

M. citrifolia

1. Morinda angustifolia Roxb., Hort. Beng. 15 (1814, nom. nud.) and Fl. Ind. 1: 547 (1820); Kurz, For. Fl. Brit. Burma 2: 61 (1877); Hook.f., Fl. Brit. Ind. 3: 157 (1880); Prain, Bengal Pl. 1: 420 (1903); Hara et al., Enum. Fl. Pl. Nepal 2: 204 (1979); Kanjilal et al., Fl. Assam 3: 79 (1982); Deb, Fl. Tripura State 2: 66 (1983); Dey et al., Biod. Bull. Bangladesh 1: 76 (1998); Rahman \& Das in Ahmed et al., Encyclopedia of Flora and Fauna of Bangladesh 10: 101 (2009). Type: Bangladesh, Chittagong, Dr. F. Buchanan 1797 (BM, K).

(Fig. 1)

Vernacular names: Banamali, Bansak, Baroful, Daru haridra, Deru-haridra, Harinar phul, Holdiruk, Jangli bansak, Pan-dogi, Pandusi, Rong gach, Shalimaricha (Bangla); Koba bena; Kurarong, Rang gach (Chakma); Tara bata (Marma); Nykhawkrilo, Elingba (Mog); Bot tita (Tripura).

An evergreen shrub or small tree, about $6 \mathrm{~m}$ tall. Stipules broadly triangular, acute, up to 12 $\mathrm{mm}$ long. Petioles up to $4 \mathrm{~cm}$ long. Leaves narrowly lanceolate or oblanceolate, lamina 20-36 $\times$ 6-13 cm, apex narrowly acuminate, base caudate-acuminate, glabrous. Cymes terminal, lateral and leaf-opposed; peduncles up to $12 \mathrm{~cm}$ long. Flowers 5-merous, sweet scented, heterostylous, arranged on globose heads which gradually elongates as a small compound fruit; hypanthium fused below; calyx truncate; corolla white, entirely glabrous, tube narrow, up to $31 \mathrm{~mm}$ long, lobes spreading, elliptic, salver shaped, up to $15 \mathrm{~mm}$ long; filaments very short, anthers included; styles slender, stigma included or partly exserted. Fruits turbinate, few fruits set in each head, mostly free, turbinate, and black when dry. Flowering and fruiting period: December to September.

Ecology: Along the edges of forests. 
Geographical distribution: India, Nepal, Bangladesh and Myanmar.

Occurrence in Bangladesh: It occurs almost throughout Bangladesh.

Status of occurrence: Common and widespread.
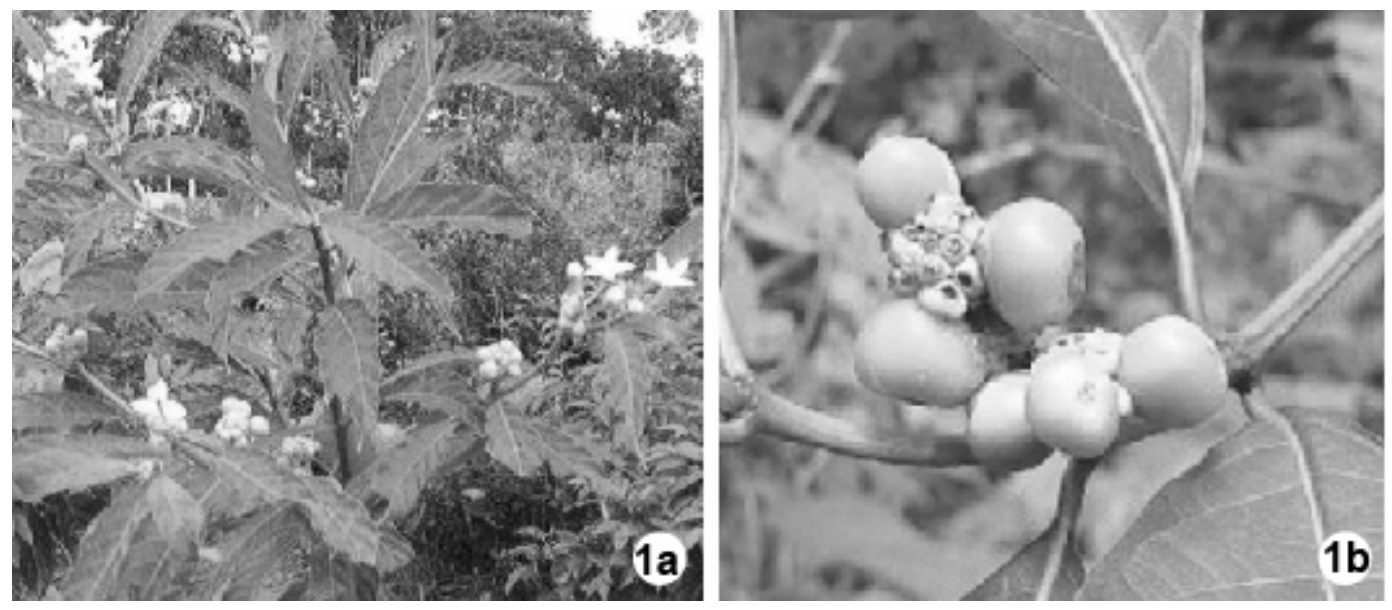

Fig.1. Morinda angustifolia Roxb.: (a) habit and (b) a fruit.

Specimens examined: Bandarban: Chimbuk Road, 15.05.1986, Alam 5592 (BFRIH); Ruma, 07.09.1987, Alam EB 01 (BFRIH). Chittagong: Chittagong, locality unknown, 05.01.1851, Hooker s. n. (K); Chittagong, locality unknown, 23.03.1876, Lister 211325 (CAL); Banskhali, Jaldi Range, Bailtali chara, Katuamali, 09.12.1920, Cowan 1627 (E 00079959); Banskhali, Jaldi Range, Tabaillya, 03.01.1921, Cowan 2225 (E 00079964); Banskhali, Sadhanpur, 24.05.1996, Rahman \& Dev 235 (HCU); Baniarchara, Dipterocarps forest, 28.03.1998, Rahman \& Wilcock 2600 (HCU); Banskhali, Sadhanpur, 29.12.2006, Sujit \& Prodip 6514 (HCU); Chunati, 17.07.2009, Sujit \& Rahman 6583 (HCU). Chittagong Hill Tracts: locality unknown, 02.1940, Mukerjee 81 (CAL). Comilla: Choudhagram, Vat para, 08.02.1979, Huq 4254 (DACB 17107). Cox's Bazar: Upper Rezu Range, Khuniapalong, 21.03.1920, Cowan 61 (E 00079961); Whykeong Forest, 07.04.1949, Sinclair 5709 (DACB 17065); Ukhia, 16.03.1979, Rahman 830 (DACB 17061); Teknaf, 16.09.1979, Maesen 3761 (K); Ramu, Upper Rezu Reserve Range, 28.06.1997, Rahman et al. 1389 (HCU). Dhaka: Dhamrai, 25.01.1978, Huq \& Rahman H 3788 (DACB 17109). Dinajpur: Thakurgaon, Singura, 15.01.1974, Khan \& Huq 3598 (DACB 17089); Biral, Ronia, 27.08.1998, Mia, Harun \& Nasir 4385 (DACB 28581). Gazipur: Rajendrapur, Senanibas, 16.06.2008, Tabassum (HDU). Khagrachari: Mahalchari, 03.03.1969, Alo Rani 124 (HDU); Hyanko, 14.03.1988, Alam 6024 (BFRIH). Kurigram: Paglarhat, 25.03.1990, Huq, Mia, Mahbuba \& Rezia 9552 (DACB 17077). Mowlvi Bazar: Srimangal, Lawachara, 06.04.1988, Mahfuz \& Huq 83 (DACB 17496). Mymensingh: Haluaghat, Panihata, 25.05.1989, Mia, Huq \& Rahman M 2045 (DACB 17070). Panchagarh: Tetulia, Tirnai, 24.02.1984, Mia \& Rahman M 972 (DACB 17133); Panchagarh, 26.02.1984, Rahman \& Zaman 1054 (DACB 17142). Rangamati: Kashaliagona, 03.1880, Gamble 7933 (K, CAL 211302); Kaptai, Sitapahar, 10. 10.1920, Cowan 1355 (E 00079963); Kaptai, 11.04.1986, Khan 7650 (DACB 17049). Rajshahi: Rohanpur, 12.06.1975, Huq 1223 (DACB 17101); Nachal, 25.10.1989, Rahman \& Mia 2331 (DACB 24450). Rangpur: Banubari, 17.01.1974, Khan \& Huq 3705 (DACB 17099). Sylhet: 
Sylhet, locality unknown, 21.12.1884, Hooker (CAL); Tamabil, Jafflong, 20.10.1986, Huq \& Mia H 7906 (DACB 17064); Jaintapur, Tamabil (Sripur), 05.04.1988, Mahfuz, Huq \& Momtaz 10 (DACB 17138); Srimongal, Lawachara forest, 28.09.2008, Sujit 6523 (HCU). Thakurgaon: Sadar, Ghanibishpur, 07.08.1998, Khan \& Harun 10069 (DACB 28380).

2. Morinda citrifolia L., Sp. Pl. 176 (1753); Kurz, For. Fl. Brit. Burma 2: 59 (1877); Hook.f., Fl. Brit. Ind. 3: 155 (1880); Raizada, Fl. Chittagong in Indian Forester: 251 (1941); Sinclair, Bull. Bot. Surv. Bengal: 97 (1956); Ridsdale, Rev. Handb. Fl. Ceylon 12: 322 (1998); Rahman \& Das in Ahmed et al., Encyclopedia of Flora and Fauna of Bangladesh 10: 101(2009). Type: India, Hort. Mal. 1: t. 52.

(Fig. 2)

Synonyms: M. bracteata Roxb. (1824) - Type: India, Roxburgh s.n. (K); M. citrifolia var. bracteata (Roxb.) Hook. f. (1880).

Vernacular names: Ach, Banach, Barachand, Haldi kachu, Haldi-kunch, Hardi, Hurdi, Noni, Ronch, Tufania (Bangla).

A shrub or small tree. Stems obtusely 4-angled, glabrous. Stipules broadly triangular, obtuse. Petioles short. Leaves elliptic to broadly elliptic to obovate, lamina 10-30 x 6-15 cm, glabrous, membranous, apex acute, base acute to cuneate. Inflorescences in dichasial cymes, condensed and aggregated into heads, borne on peduncles, the head ellipsoid, solitary, leaf opposed, at alternate node; bracts foliaceous. Flowers 5-merous; calyx tube or hypanthium urceolate, adnate to the ovary; corolla infundibular, lobes lanceolate, acute, glabrous, the throat pubescent, white; stamens epipetalous, filaments short, hairy, anthers oblongoid, introrse, dehiscence longitudinal; styles up to $14 \mathrm{~mm}$ long, stigma bi-lobed, ovary 2 chambered, ovules solitary in each locule. Fruits compound, smooth and glossy on fleshy heads; seeds ovoid. Flowering and fruiting period: May to November.
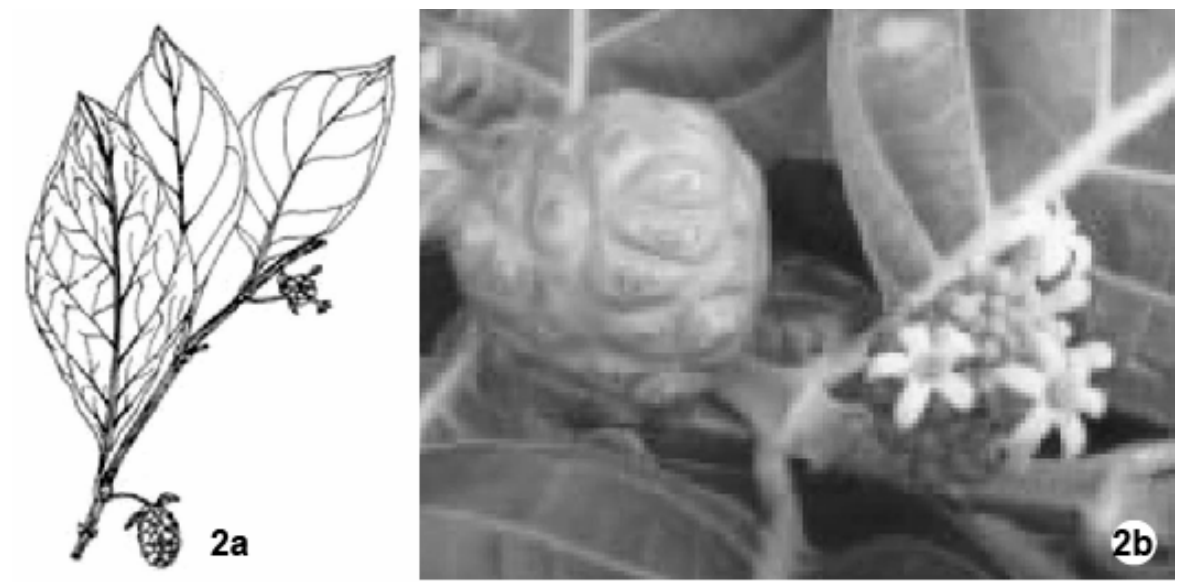

Fig. 2. Morinda citrifolia L.: (a) habit sketch and (b) flowers and fruits.

Ecology: Plain lands, especially salty river banks and coasts.

Geographical distribution: Sri Lanka, India, Pakistan, Bangladesh, Myanmar, Malaysia, China, Australia and the Pacific islands.

Occurrence in Bangladesh: It seems to occur throughout Bangladesh. 
Status of occurrence: Common and widespread.

Specimens examined: Bhola: Char Fashion, 27.02.1989, Mia \& Rahman H 9068 (DACB 17076). Chittagong: Hat Hazari, 05.01.1851, Hooker s. n. (K); Sitakunda, 06.01.1851, Hooker \& Thomson (K); Sandwip, Kalapani, 09.02.1988, Mia \& Mahfuz 1448 (DACB 17128); Domekhali, 06.08.1971, Alam Tx57 (BFRIH). Cox's Bazar: Jadipahar, 19.02.1971, Khan \& Huq K 2476 (DACB 17100); Cox’s Bazar, 22.04.1976, Shahjahan 2 (E 00079968, DACB); Koranta Quarter, 11.08.1943, Sinclair 3102 (E 00079969); Teknaf, St. Martin's Island, 29.01.1999, Rahman et al. 4187 (ABD, HCU). Dhaka: Ramna Park, 19.02.1980, Mamtaz 233 (DACB 17069). Dinajpur: Ramsagar, 14.01.1974, Khan \& Huq K 3561 (DACB 17102); Biral, Mayer Pukur, 28.08.1998, Mia \& Harun 4390 (DACB 28580). Gazipur: Chandra Sal forest, 05.08.1976, Khan et al. K 4188 (DACB 17123). Faridpur: Bagat, Magura road, 06.01.1976, Huq, Rahman \& Mia H 1975 (DACB 17096). Laxmipur: Ramgoti, 28.11.2009, Sujit s.n. (HCU). Manikgonj: Targhat, 06.06.1978, Soejarto \& Rahman 4975 (DACB 17124). Noakhali: Hatiya island, 16.03.1987, Huq \& Mia H 8280 (DACB 17066); Ramgonj, Chatkhil, Dowlatpur, 15.01.1999, Alam 254 (BFRIH); Basur Hat, Kompanigonj, 27.08.2009, Sujit's collector Sajal s.n. (HCU). Rajshahi: Godagari, 17.11.1988, Huq 5558 (DACB 17068). Rangamati: Madhabchara, 27.10.1995, Mohiuddin \& Mizan 75 (BFRIH); Bagaichari, 30.05.1998, Rahman et al. 2973 (HCU). Tangail: Madhupur, 15.07.1987, Huq 8451 (DACB 25407).

Note: Roots are employed by the natives to dye red (Roxb. 1832). Due to its medicinal properties, the plant is collected and used by local herbalist without considering its regeneration.

3. Morinda persicaefolia Ham., Trans. Linn. Soc. 13: 535 (1826); Kurz, For. Fl. Brit. Burma 2: 61 (1877, reprt. 1974); Hook.f., Fl. Brit. Ind. 3: 157 (1880); Prain, Bengal Pl. 1: 420 (1903, reprt. 1963); Rahman \& Das in Ahmed et al., Encyclopedia of Flora and Fauna of Bangladesh 10: 102 (2009).

(Fig. 3)

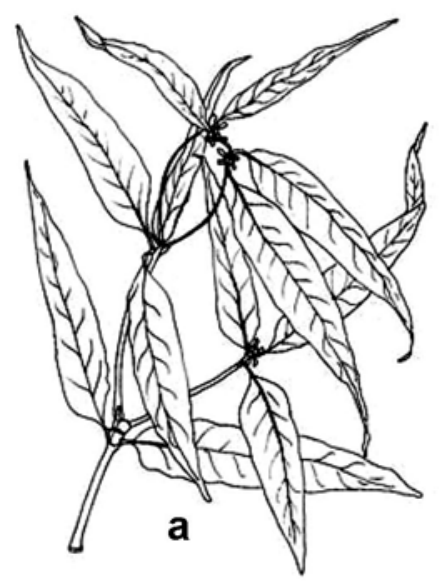

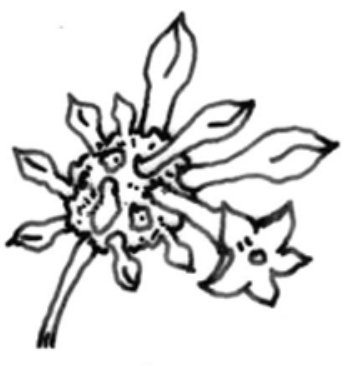

b

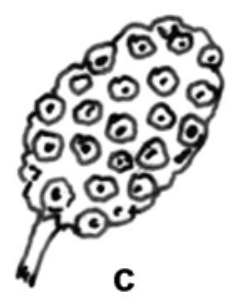

Fig. 3. Morinda persicaefolia Ham.: (a) habit sketch, (b) an inflorescence and (c) a fruit.

Synonym: M. lanceolata Wall. Cat. 8435 (1828 ined.).

Vernacular names: Kobabena, Rong gach (Chakma); Areng paing, Kobaban (Marma).

An evergreen, small low diffuse shrub, up to $1 \mathrm{~m}$ tall; branches flexuous, glabrous. Stipules subulate-acuminate to acute, from a broad base. Petioles up to $10 \mathrm{~cm}$ long. Leaves variable in 
breadth, obovate-lanceolate or oblanceolate or linear caudate-acuminate narrowed into the petiole, up to $15 \mathrm{~cm}$ long. Inflorescences a compound head. Flowers 5-merous, sessile, in a small sessile or shortly peduncled head arising from opposite or alternately single leaves or from the base of the end leaf; calyx truncate; corolla funnel shaped, glabrous, tubes up to $2 \mathrm{~cm}$ long, lobes oblong, blunt with glabrous throat. Fruits smooth, cherry sized, irregularly oblong. Flowering and fruiting period: March to August.

Ecology: Over bushes besides canal.

Geographical distribution: India, Bangladesh, Myanmar and Singapore.

Occurrence in Bangladesh: It is known to occur in Bandarban and Chittagong districts

Status of occurrence: Rare.

Specimens examined: Bandarban: Sadar, 03.05.1977, Huq 3345 (DACB 17088); Bakaghata, Chandraghona, 29.11.1983, Khan, Huq \& Rahman 6579 (DACB 17083); Chimbuk road, 15.05.1986, Alam 6593 (BFRIH); Bonchari, 28.06.1987, Das \& Alam 5857 (BFRIH); Thanchi Road, Guishap jiri, 03.05.1998, Rahman et al. 2870 (ABD, HCU). Chittagong: Baroiyadhala, 14.03.1964, Khan 841 (E 00079966, DACB); Hazarikhil, 14.03.1970, Rahman 13 (E 00079965, DACB); East side of Sitakundo, 21.03.1970, Mohammad 318 (BCSRIH); Hazarikhil, Baroiyadhala, 21.06.1979, Mia \& Rahman 57 (DACB 17087).

4. Morinda pubescens Smith in Rees, Cycl.: 24. n. 3 (1813). M. tinctoria Roxb., Hort. Beng.: 15 (1814) nom. nud. and Fl. Ind. 1: 543 (1824), non Noronha (1790); Hook.f., Fl. Brit. Ind. 3: 156 (1880); Prain, Bengal Pl. 1: 419 (1903). Type: India, Roxburgh s.n. (BM).

(Fig. 4)

Synonyms: M. tomentosa Heyne ex Roth.(1821); M. coreia Buch.-Ham. (1822): Morinda exserta Roxb. (1824) - Type: India, Bengal, Roxburgh s.n. (K).

Vernacular names: Ach (Bangla); Khujai (Chakma).
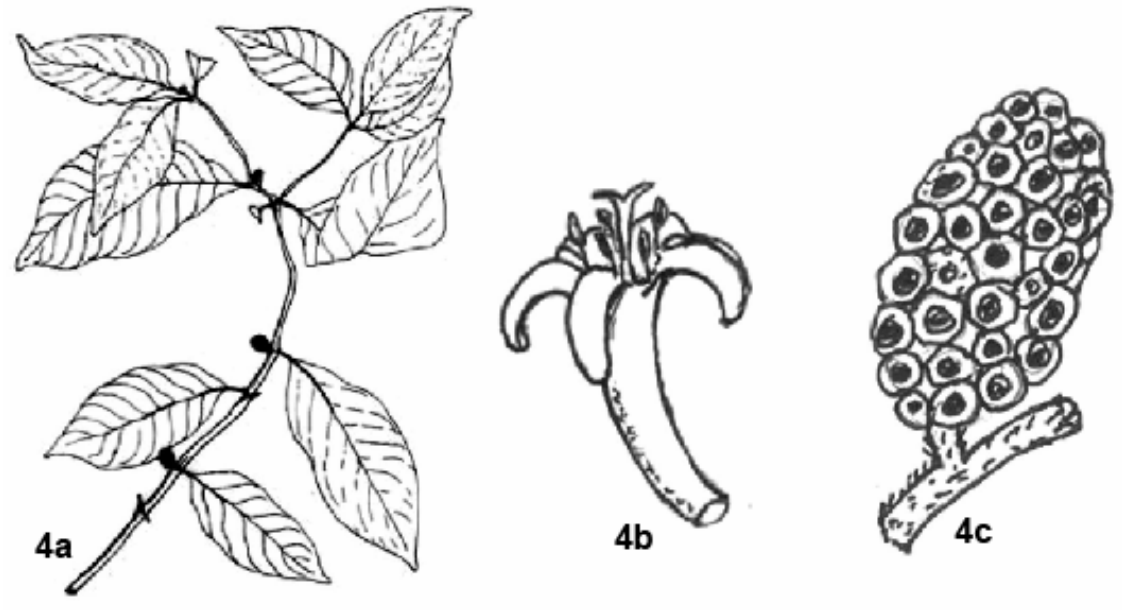

Fig. 4. Morinda pubescens Smith: (a) habit sketch, (b) a flower and (c) a fruit.

A small or middle sized tree up to $10 \mathrm{~m}$ tall, bark thick, rough, fissured and somewhat corky; branchlets often with a characteristic thin pallid to yellowish bark. Stipules deltoid to narrowly triangular, up to $8 \mathrm{~mm}$ long, apex acute, sometimes slightly bifid. Petioles up to $2.5 \mathrm{~cm}$ long. Leaves broadly elliptic to linear-lanceolate or obovate, lamina 6-20 $\times 5-8 \mathrm{~cm}$, above glabrous, 
below glabrous or tomentose, apex acute to acuminate, base acute to cuneate. Inflorescence solitary, axillary or rarely terminal, ovoid or globose, capitulum, often appearing leaf-opposed or subtended by reduced leaf, pedicels up to $3.5 \mathrm{~cm}$ long. Flowers 5-merous; calyx limb short, truncate; corolla white, tubes up to $15 \mathrm{~mm}$ long, inside glabrous in the throat, lobes oblong, 6-8 $\mathrm{mm}$ long, recurved; anthers oblong, up to $5 \mathrm{~mm}$ long; stigma 2-lobed, styles up to $18 \mathrm{~mm}$ long. Drupes, coalescent into a globose or ovoid fleshy head, up to $3 \mathrm{~cm}$ across; seeds oblong, pyrenes stony. Flowering and fruiting period: May to February.

Ecology: Grows on hilly slopes and valley areas.

Geographical distribution: Sri Lanka, India, Bangladesh, Malaya Archipelago.

Occurrence in Bangladesh: It has been collected from Bandarban, Chittagong and Dinajpur districts.

\section{Status of occurrence: Rare.}

Specimens examined: Bandarban: Bandarban, 03.05.1977, Huq 3330 (DACB 17119); Balaghat, 05.06.2000, Wahab \& Yusuf 1379 (BCSRIH). Chittagong: Baroiyadhala, 12.04.1994, Khan et al. K 9016 (DACB 26857). Dinajpur: Ram Sagar, 25.11.1995, Students' collection (SKHDU).

5. Morinda umbellata L., Sp. Pl.: 176 (1753); Hook.f., Fl. Brit. Ind. 3: 157 (1880); Heinig, List Chittagong 35 (1925); Ridsdale, Rev. Handb. Fl. Ceylon 12: 321 (1998); Rahman \& Das in Ahmed et al., Encyclopedia of Flora and Fauna of Bangladesh 10: 103 (2009). Type: Sri Lanka, Herb. Hermann. M. pada-vara Juss. ex Schult., Syst. Veg. 5: 216 (1819). Type: India, Hort. Mal. 7: t. 52. M. scandens Roxb., Fl. Ind. 2: 202 (1824). Type: India, Roxburgh s.n. (K). Vernacular name: Gassa lata (Bangla).

(Fig. 5)
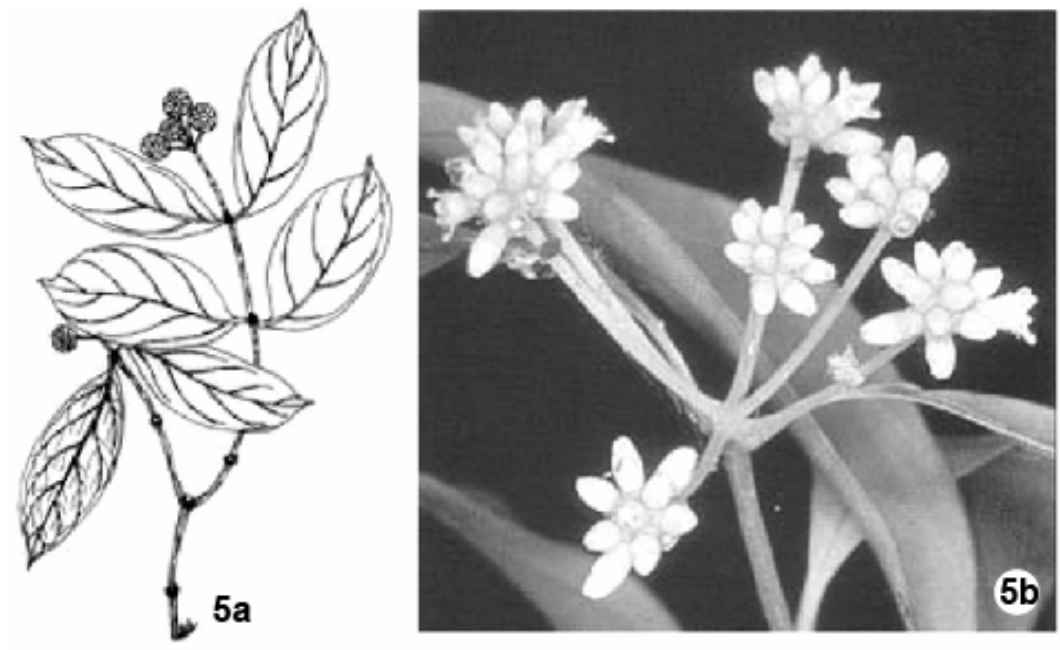

Fig. 5. Morinda umbellata L.: (a) habit sketch and (b) habit and inflorescence.

A climbing shrub, up to $20 \mathrm{~m}$ long, slender, sarmentose. Stipules truncate, up to $15 \mathrm{~mm}$ long. Petioles up to $1 \mathrm{~cm}$ long. Leaves elliptic to elliptic-lanceolate, rarely ovate, lamina 6-10 x 2-5 cm, glabrous, apex acute to acuminate, base acute to cuneate, lateral nerves up to 8 pairs. Inflorescence a terminal umbel, heads small, less than $15 \mathrm{~mm}$ in diam., globose; pedicels up to 3 
cm long. Flowers 4-merous; calyx limb short, truncate; corolla tubes very short, lobes up to $8 \mathrm{~mm}$ long, oblong-ovate, much longer than the tube, inside villous in the throat; anthers oblong, up to 1 $\mathrm{mm}$, filament short, included; stigmas bi-lobed, styles $4 \mathrm{~mm}$ long. Drupes pyriform, irregularly lobed; seeds oblong. Flowering and fruiting period: June to September.

Ecology: Sea shores to hill slopes.

Geographical distribution: Sri Lanka, India, Bangladesh, Myanmar, Indo-Malaya and Australia.

Occurrence in Bangladesh: It occurs in Chittagong and Cox's Bazar districts.

Status of occurrence: Rare.

Specimens examined: Chittagong: Garjania, 06.1920, Cowan 707 (E 00079967); Harbang, 11.06.1979, Khan, Huq \& Rahman K 5563 (DACB 17125). Cox's Bazar: Upper Rezu Reserve Range, 28.06.1997, Rahman et al. 1386 (ABD, HCU).

\section{Acknowledgements}

The authors are grateful to the authorities of the BM, CAL, E, K, BFRIH, BCSIRH, DACB, HCU and SKHDU for providing facilities to examine specimens and to consult libraries.

\section{References}

Dey CK, MA Rahman and CC Wilcock 1998. An enumeration of the tree species of Chittagong district. Biod. Bull. Bangladesh 1: 74-78.

Heinig RL 1925. List of plants of the Chittagong Collectorate and Hill Tracts. The Bengal Government Branch Press, Darjeeling.

Hooker JD 1880-1881. Flora of British India 3: 17-210. L. Reeve and Co., Kent.

Kurz WS 1974. Forest Flora of British Burma. (reprint) 2: 4-76. Bishen Singh Mahendra Pal Singh, Dehra Dun.

Mabberley DJ 1997. The Plant-Book (2 ${ }^{\text {nd }}$ ed.). Cambridge Univ. Press, Cambridge.

Prain D 1903. Bengal Plants. 1: 400-425. Botanical Survey of India, Calcutta.

Rahman MA and SC Das 2009. Rubiaceae. In: Encyclopedia of Flora and Fauna of Bangladesh. 10: 38-159. Ahmed ZU, MA Hassan, ZNT Begum, M Khondker, SMH Kabir, M Ahmed and AT Ahmed (Eds). Asiat. Soc. Bangladesh, Dhaka.

Raizada MB 1941. On the flora of Chittagong. Indian Forester 67(5): 245-254.

Rashid MH, MA Rahman and MS Khan 1999. A checklist of the Rubiaceae of Bangladesh. Bangladesh J. Pl. Taxon. 8(2): 75.

Roxburgh W 1814. Tetrandia Monogynia. Hortus Bengalensis. Boerhaave Press, Leiden.

Roxburgh W 1832. Tetrandia Monogynia in Willium Carey’s Flora Indica; or descriptions of Indian plants. Mission Press, Serampore.

Sinclair J 1956. The Flora of Cox’s Bazar, East Pakistan. Bull. Bot. Soc. Beng. 9(2): 84-116.

Voigt JO 1845. Hortus Suburbanus Calcuttensis, Catalogue of the plants which have been cultivated in the Honb. East India Company's Botanical Garden, Calcutta and in the Serampore Botanical Garden. Bishop's College Press, Calcutta.

Wallich N 1828-1849. A numerical list of dried specimens of plants in the East Indian Company's Museum. (Ined.). 